\title{
Demand planning approaches employed by clothing industry stakeholders in Gauteng, South Africa
}

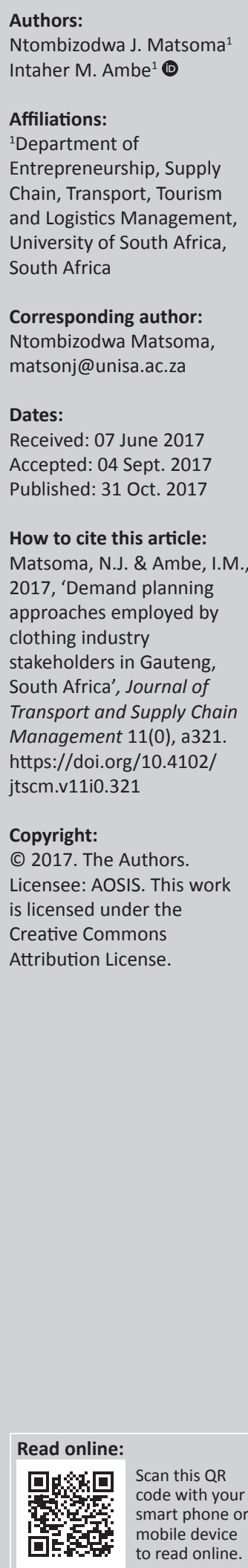

Background: The decline in the productivity of the South African clothing industry was attributed to changing trends in the number of clothing production organisations, which together with a decline in manufacturing output and a fluctuation in employment had all contributed to complexities in demand planning.

Purpose: This article investigates demand planning approaches in the clothing industry in Gauteng.

Method: A descriptive study was conducted based on a structured questionnaire.

Findings: The results revealed that both hierarchical and optimal approaches should be considered in clothing manufacturing.

Managerial implications: In order to improve demand planning practices in the clothing industry, managers are recommended to apply hierarchical and optimal demand planning approaches, which might bring about improvements to demand planning in the Gauteng clothing industry.

Conclusion: It is recommended that clothing manufacturers consider the types of product offering before making decisions about adopting the hierarchical or optimal demand planning approaches. When planning for basic clothes, manufacturers should consider a hierarchical demand planning approach, whereas the optimal demand planning approach is recommended for fashion clothes.

\section{Introduction}

The status of the South African clothing industry reflects a low-income market and low productivity (Fibre Processing Manufacturing Seta [FP\&M Seta] 2014:3; Nattrass \& Seekings 2012:7). Seen in this light, it is crucial to plan for demand in the clothing industry because clothes are regarded as highly desirable products, symbolising the status quo of individuals (Hong 2015:323). In 2012, many clothing manufacturers relocated their factories to bordering countries, while in some instances, the challenges were so serious that some clothing factories closed down their operations completely (Nattrass \& Seekings 2012:7). The number of clothing manufacturers in South Africa is still declining (Isaacs 2016). The reason, according to Isaacs (2016), is because of imports from other countries, which had a detrimental effect on their operations. The current research was conducted in a quest to determine the approaches to demand planning adopted by the South African clothing industry, particularly in the Gauteng province, to determine whether proper demand planning can add value to the South African clothing industry.

Demand planning approaches are critical in the decision-making processes of production organisations (Belmokhtar, Herrera \& Thomas 2010:1). Production organisations often adopt certain approaches to reduce the complexity of production processes when planning for customer demands (Albey \& Bilge 2011:3320). Demand planning approaches, such as the modelling of uncertainties, aggregation and disaggregation of processes, and the replacement of random processing with averages are commonly used by production organisations (Nielsen \& StegerJensen 2006). Manufacturing organisations realise that for these approaches to succeed in reducing production complexities, either a hierarchical or an optimal approach to production decisionmaking must be established (Nielsen \& Steger-Jensen 2006).

\section{Problem statement}

Hierarchical and optimal demand planning approaches are perceived to assist production organisations in making appropriate decisions on production planning based on the product 
demand. Authors such as Nielsen and Steger-Jensen (2008) and Omar and Teo (2007:1029) explored how these approaches assist in improving sound decision-making in the production industry. Chan and Chan (2010:1195) also explored the optimisation of the hierarchical demand planning approach for sound decision-making in the clothing production industry. From a South African perspective, authors such as Amusa, Amusa and Mabungu (2009) focused on aggregate demand planning for electricity; Priest (2005), Sen (2008), Wark (2006) and Steytler and Powell (2010:6) explored selected components of demand planning such fashion, clothing estimations and recession. Also Vlok (2006); Nattrass and Seekings (2012) and Oberhofer (2012) explored various components of the SA clothing industry such as clothing imports, wage setting implications and fashion designing. These studies contribute to demand planning, and there is need to determine which demand planning approaches the case organisations pursue. However, there are limited studies on demand planning approaches employed by the various clothing stakeholders to improve production planning, in South Africa. Hence, this article seeks to investigate the demand planning approaches employed by various stakeholders in the Gauteng clothing industry.

The remaining sections of this article cover the literature review, research methodology, ethical consideration, data analysis, results, discussions, limitations of the study and conclusion.

\section{Literature review}

The literature review covers the history of the South African clothing industry, clothing industry stakeholders in South Africa and approaches to demand planning.

\section{History of the South African clothing industry}

The South African clothing industry originally started in Cape Town and then spread to Johannesburg in the 1920s and 1930s (Nattrass \& Seekings 2012:2). After the Second World War it increased in volume and employment (Salm 2002:7). In 1950, the level of employment in the South African clothing industry was sitting at 50000 workers. In 1980, there were 170000 people employed in the clothing industry, which increased to the highest point of 228053 workers in 1996, and thereafter decreased to 142865 workers in 2005. In 2013, employment figures reflected that only 80000 people were employed in the South African clothing industry (Media Club South Africa 2015:14; Nattrass \& Seekings 2012:2; Vlok 2006:229). The reason, according to Nattrass and Seekings (2012:7), is that the global trade and the global recession have caused certain clothing manufacturers to relocate some of their manufacturing operations to other less expensive locations because of the intense local competition and global economic downturn. In some cases, South African clothing factories experienced serious challenges resulting from these global factors, and some of the clothing factories decided to terminate their clothing manufacturing operations (Nattrass \& Seekings 2012:7).
In effort to promote all-Africa production, the South African clothing industry has incorporated fashion products manufactured in the rest of Africa (Oberhofer 2012:67). In 2014, African designs from more than 180 African clothing producers were showcased at trade events hosted at the Cape Town International Convention Centre (African Clothing Industry in Spotlight 2014). Various stakeholders who contribute towards the productivity of the South African clothing industry will be discussed next.

\section{The South African clothing industry stakeholders}

The South African clothing industry comprises three key stakeholders: fabric suppliers, fashion designers and clothing manufacturers.

\section{Fabric suppliers}

Fabric is crucial in the clothing industry because it is used to produce final garments in various styles and colours. Therefore, fabric suppliers can be seen as some of the main contributors to the functioning of this industry. Demand planning in the clothing industry should, however, start with the suppliers of raw materials that are essential for the manufacturing of fabric. Fabric is made by spinning yarns produced from, among others, cotton or wool. South Africa is a top producer of wool for the production of clothing fabric, and the country is also one of the top five mohair-producing countries in the world. In addition, South Africa harvests 40000 tons of cotton on an annual basis (SouthAfrica.info 2015). There are 3400 cotton suppliers and 15000 wool suppliers in South Africa (Salm 2002:17). Raw materials, like cotton or wool, are ordered from first-tier suppliers for use in the manufacturing plant. Processing machines transform these raw materials into fabrics (Isenheim 2006:4). Clothing factories can then order the fabrics for the production of clothing from the second-tier suppliers such as A B C Fabrics, A T Textiles CC Adam N Eve Fabrics, Adonis Knitwear Holdings (PTY) LTD and many other second-tier suppliers (Schreiber 2013; Southern African Clothing and Textile Workers Union [SACTWU] 2012).

\section{Fashion designers}

Fashion design is a form of artistic talent that is devoted to the construction of garments and other decorations or trimmings (Fibre2Fashion.com 2017). Fashion designing involves the creation of various clothing items according to fashion trends that have a relatively short life cycle (Williams 2015:12). According to Oberhofer (2012:67), fashion designers are more involved in creating various clothing brands than clothing manufacturers are. As fashion originated from global cities such as Paris, London and New York (Oberhofer 2012:65), the fashion industries in these cities are, therefore, regarded as the main fashion trend setters. Fashion centres that have existed for many decades are still operating today and still dominate the production of fashion clothes in various states and regions (Skov 2011:139). Fashion production is controlled by market forces consisting of individual requirements and desires (Shen et al. 2013:266). 
As a result, the fashion industry has been divided into two different industries: one producing international garments and the other producing domestic clothing styles (Skov 2011:138). In the 1920s and 1930s, Paul Poiret from Paris started to include African designs in his creative clothing designs (Oberhofer 2012:66). Thus, Africa became involved in global fashion, which resulted in the growth of fashion in African countries. This resulted in an increase in the number of fashion designers in African countries, including South Africa (Oberhofer 2012:83).

South African fashion designers are competing in the global fashion world (Oberhofer 2012:67). According to Skov (2011:138), fashion centres are localised where fashion design is conducted. In South Africa, fashion centres were established in the city of Johannesburg, where style makers such as Stoned Cherrie were established and have been developing (Oberhofer 2012:71). State initiatives have assisted Stoned Cherrie to become one of the leading fashion brands in South Africa. Other South Africa fashion brands include, among others, Luxion Kulcha, Thula Sindi, Black Coffee, African Queen and Thunderstorm (Schreiber 2013). According to the SA fashion week (2015), 72 fashion designers were identified in the Gauteng province. Oberhofer (2012:71) confirmed that luxury fashion brands include fashion designers who operate as owners of small clothing organisations in Gauteng.

\section{Clothing manufacturers}

Clothing manufacturing is critical because clothes are a basic requirement for all people (Chaudhary 2011:2). According to the report from SACTWU (2012), some of the clothing manufacturers that are situated in Gauteng, South Africa, are New Age, Navada, Thorn clothing, Millenium Fashion Manufacturing CC and many more. Clothing manufacturers are directly involved in producing basic clothes and fashion clothes from the fabric that was manufactured by fabric suppliers. Authors, such as Nattrass and Seekings (2012:6) and Staritz and Morris (2013:9), posit that some clothing factories form the cut, trim and make (CTM) industry. The CTM factories are the ones accountable for cutting and trimming clothing fabrics and making complete garments according to the requirements of clients. Clothing production factories can outsource the manufacturing of clothes to the CTM factories to meet clothing demands. However, the manufacturers have the final say when it comes to designing the clothes they require (Staritz \& Morris 2013:9).

The key clothing industry stakeholders - fabric suppliers, fashion designers and clothing manufacturers - each have a unique character and function. Their roles and responsibilities towards clothing production differ. However, each one's special attributes make a valuable contribution towards improving the industry's productivity. This can clearly be seen in the clothing value chain illustrated in Figure 1.

From Figure 1 it is clear that the expertise of each of the three clothing industry stakeholders is required for the functioning of the clothing industry. Their expertise also contributes towards improving the economic wealth of the country, as they are involved in satisfying the needs of retail stores and clothing customers. In order to meet customers' demands they need to plan properly by making use of different demand planning approaches.

\section{Approaches to demand planning}

Demand planning can be defined as the estimation of customer needs and other planning measures, as well as actions that illustrate planning in conjunction with other participants in the value chain (Rexhausen, Pibernik \& Kaiser 2012:269). Organisations can use various demand management approaches to make sound decisions in their manufacturing processes that will alleviate improper demand planning practices (Bowersox et al. 2013:139). Sethi et al. (2002:6) distinguish two generic types of demand planning approaches, namely, the hierarchical and optimal approaches. These approaches are perceived to assist production organisations to make appropriate production planning decisions to meet product demand. The hierarchical and optimal approaches are considered to be production improvement decision approaches.

\section{Hierarchical demand planning approach}

The hierarchical approach was introduced in 1990 by Bertrand and Wortmann (Albey \& Bilge 2011:3319). It is considered relevant to assist organisations with production decisions across value-chain linkages (Pycraft et al. 2013:13). The hierarchical approach plans to solve the problem by using various dimensions in the product planning decision-making process (Belmokhtar et al. 2010:1). This demand planning approach tool separates operation process challenges into smaller sub-challenges that can be managed with a suitable managing tool, gathering products and subsequently separating them into smaller sub-units (Belmokhtar et al. 2010:1; Sethi et al. 2002:6). This implies that the hierarchical planning approach is based on decisions which include all the dimensions in the production plan for products.

According to Pycraft et al. (2013:13), it is important to consider the following three groups that are involved in demand satisfaction when planning for demand in the

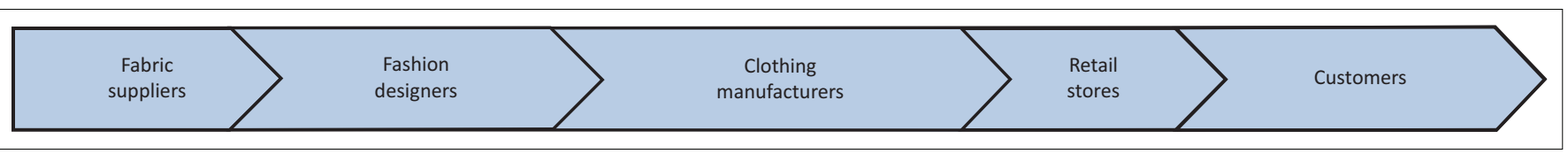

Source: Adapted from Isenheim, M., 2006, Quotas on textiles and clothing: A review, viewed 30 August 2012, p. 4, from http://www.grin.com/en/e-book/51307/quotas-on-textiles-and-clothing-areview and Thomassey, S., 2010, 'Sales forecasts in clothing industry: The key success factor of the supply chain management', International Journal of Production Economics 128(2), 478. https:// doi.org/10.1016/j.ijpe.2010.07.018

FIGURE 1: The clothing supply chain. 
manufacturing plant: external suppliers, internal suppliers and internal customers. This suggests that there is a need for production decision plans to be separated across various organisational dimensions and supply chain networks to improve demand planning. Thomassey (2014:13) adds that demand planning in the clothing industry is a challenge as the industry constitutes various stock keeping units (SKUs), which become a challenge when product grouping is performed. As a result, uncertainties will emanate when planning and scheduling clothing production. The hierarchical approach aims to reduce these uncertainties by determining the necessary resources required for each specific product group in the value chain network (Belmokhtar et al. 2010:1). Manufacturing equipment, material handling, backlogs, actual manufacturing and the inherent cost are taken into account (Albey \& Bilge 2011:3322).

The hierarchical approach accepts that production decisions should combine either various dimensions in the organisation or the partners in the product value chain without any interventions (Nielsen \& Steger-Jensen 2006:2). The hierarchical approach combines the volumes of production per product group for a specific production in an unlimited period and incorporates several plans (Nielsen \& StegerJensen 2006:2). In addition, the hierarchical approach operates effectively in a stable production process. Nielsen and StegerJensen (2008:58) suggest that it should be used in intermediateto large-volume operations with the aim of minimising the total cost of production.

A summary of the characteristics of the hierarchical approach to production demand planning is presented in Figure 2.

\section{Optimal demand planning approach}

The optimal approach is also one of the demand management approaches, which assist in the production decision-making of organisations (Albey \& Bilge 2011:3320). The optimal approach is a relevant tool that can be used to address short manufacturing plans, multiple production processes, and also in anticipating real capacity utilisation (Sethi et al. 2002:6). It is important to acknowledge that production planning and scheduling become a challenge when there are

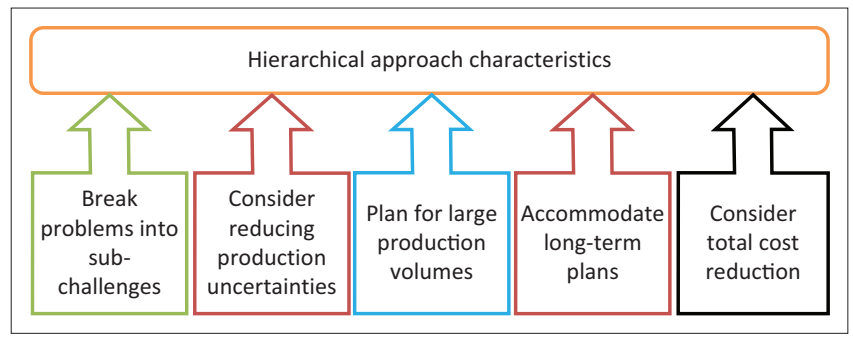

Source: Belmokhtar, S., Herrera, C. \& Thomas, A., 2010, 'A general approach for hierarchical production planning considering stability', in Proceedings of the 3rd International Conference on Information Systems, Logistics and Supply Chain, Creating Value through Green Supply Chain, ILS 2010 - Casablanca (Morocco), April 14-16, 2010, pp. 1-7; Nielsen, P. \& StegerJensen, K., 2008, 'Demand planning \& control - Handling multiple perspectives through a holistic approach to hierarchical planning', in T. Koch (ed.), Lean business systems and beyond, p. 58, Springer, Boston, MA and Sethi, S., Yan, H., Zhang, H. \& Zhang, Q., 2002, 'Optimal and hierarchical controls in dynamic stochastic manufacturing systems: A survey' Manufacturing \& Service Operations Management 4(2), 6. https://doi.org/10.1287/ msom.4.2.133.281

FIGURE 2: Characteristics of the hierarchical approach to demand planning. fluctuations in product demand (Nenni, Giustiniano \& Pirolo 2013:4). Hence, when planning for clothing production, short- and long-term planning periods need to be taken into consideration (Thomassey 2014:12). Where organisations face vigorous interventions across various operational dimensions in their supply chain networks, the optimal approach is crucial to ensure quick responses in the production planning processes (Nielsen \& Steger-Jensen 2008:57).

When evaluating the production capacity for product demand planning, it is crucial that the facility should be able to implement the required changes to the production aspects (Albey \& Bilge 2011:3320). Challenges regarding scheduling and time, anticipated capacity, equipment and manufacturing blockages need quick decisions for operational control (Albey \& Bilge 2011:3322). This necessitates a flexible control system for short-term planning (Sethi et al. 2002:6). The optimal approach is suitable for dealing with these kinds of challenges, as well as the challenges posed by multiple production processes and the utilisation of real capacity (Sethi et al. 2002:6). Operational solutions are gathered in the short term to satisfy the changing demand when dealing with these uncertainties in the production capacity (Sethi et al. 2002:6).

The optimal approach aims to reduce the overall costs of operation and stock holding (Sethi et al. 2002:6). This is performed through grouping products of similar production cost, inventory cost, seasonal demand and product type together in a flexible production run (Nielsen \& Steger-Jensen 2008:58).

Figure 3 presents a summary of the characteristics of the optimal approach.

The hierarchical and optimal approaches to demand planning assist manufacturing organisations in making decisions on the following: individual processes, information planning, material requirements and the utilisation of production capacity (Belmokhtar et al. 2010:1). However, there are differences between the two approaches as explained in Table 1.

Table 1 explains the difference between the hierarchical and optimal demand planning approaches. Both may be considered as effective for production planning of some categories in the clothing industry. However, the hierarchical demand planning approach seems to operate effectively on large-scale stable operation processes with minimal uncertainties (Nielsen \& Steger-Jensen 2006:2). In contrast, the optimal demand planning approach seems to function more efficiently in small flexible production operations with lots of production uncertainties (Sethi et al. 2002:6). Thomassey (2010:471) indicated that, in terms of clothing manufacturing, basic clothes are stable and constitute long manufacturing processes, whereas fashion clothes constitute constant changes and require short manufacturing processes (Oyatoye \& Fabson 2011:17). This demonstrates that the hierarchical demand planning approach may be suitable for making decisions regarding the production of basic clothes, while the 


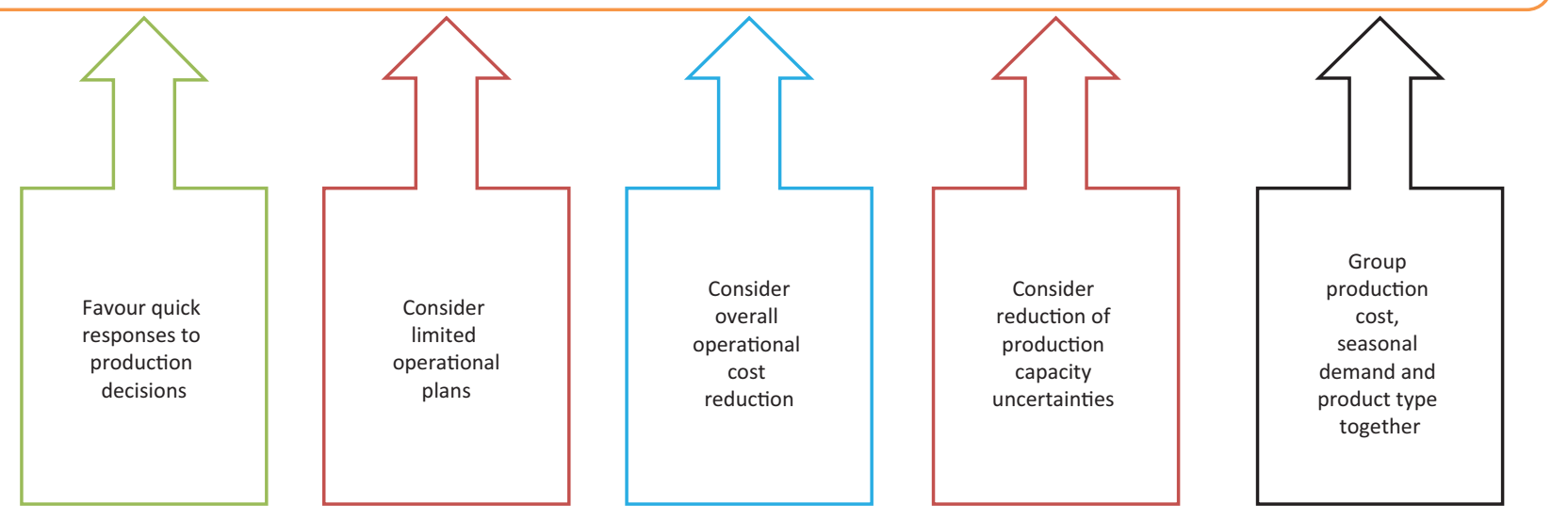

Source: Belmokhtar, S., Herrera, C. \& Thomas, A., 2010, 'A general approach for hierarchical production planning considering stability', in Proceedings of the 3rd International Conference on Information Systems, Logistics and Supply Chain, Creating Value through Green Supply Chain, ILS 2010 - Casablanca (Morocco), April 14-16, pp. 1-7; Nielsen, P. \& Steger-Jensen, K., 2008, 'Demand planning \& control - Handling multiple perspectives through a holistic approach to hierarchical planning', in T. Koch (ed.), Lean business systems and beyond, p. 58 , Springer, Boston, MA and Sethi, planning \& control - Handling multiple perspectives through a holistic approach to hierarchical planning', in T. Koch (ed.), Lean business systems and beyond, p. 58, Springer, Boston, MA and Sethi,
S., Yan, H., Zhang, H. \& Zhang, Q., 2002, 'Optimal and hierarchical controls in dynamic stochastic manufacturing systems: A survey', Manufacturing \& Service Operations Management 4(2), 6. https://doi.org/10.1287/msom.4.2.133.281

FIGURE 3: Characteristics of the optimal approach to demand planning.

TABLE 1: Distinguishing attributes of the hierarchical and optimal demand planning approaches.

\begin{tabular}{|c|c|c|}
\hline Attributes & Hierarchical demand planning approach (HDPA) & Optimal demand planning approach (ODPA) \\
\hline $\begin{array}{l}\text { Production } \\
\text { planning }\end{array}$ & $\begin{array}{l}\text { - The HDPA subdivides operation process challenges into smaller } \\
\text { challenges, each with a suitable managing tool. } \\
\text { - The HDPA combines products and subsequently divides them } \\
\text { into smaller groups. } \\
\text { - The HDPA considers production planning over an extended period. } \\
\text { - The HDPA operates effectively in a stable production process. }\end{array}$ & $\begin{array}{l}\text { - The ODPA gathers operational ideas over a limited period to satisfy a deterministic } \\
\text { demand. } \\
\text { - The ODPA lowers stockholding. } \\
\text { - The ODPA incorporates backorders into the production decision-making process. } \\
\text { - The ODPA groups production cost, seasonal demand and product type together. } \\
\text { - The ODPA considers the fact that the environment is dynamic. }\end{array}$ \\
\hline $\begin{array}{l}\text { Uncertainty } \\
\text { prevention }\end{array}$ & $\begin{array}{l}\text { The HDPA indicates uncertainties in the operation planning } \\
\text { through flow processes. }\end{array}$ & $\begin{array}{l}\text { - The ODPA considers demand as an unlimited state. } \\
\text { - The ODPA examines stochastic demand in a separate time setting. }\end{array}$ \\
\hline Forecasting & $\begin{array}{l}\text { - The HDPA considers production demand estimation and revises } \\
\text { estimations during the planning period. }\end{array}$ & $\begin{array}{l}\text { - The ODPA considers quick production demand estimation, thus making the } \\
\text { production capacity over time a limited state. } \\
\text { - The ODPA aims to find an optimal forecast on aggregate data. }\end{array}$ \\
\hline $\begin{array}{l}\text { Production machine } \\
\text { capabilities }\end{array}$ & $\begin{array}{l}\text { - The HDPA considers multiple visits of production equipment and } \\
\text { produces different products in demand, using machines in general. } \\
\text { - The HDPA considers network arrangements, as machines may } \\
\text { break and need to be repaired. }\end{array}$ & $\begin{array}{l}\text { - The ODPA considers production of single or parallel equipment this way: } \\
\text { - The ODPA acknowledges that production equipment produces at a maximum } \\
\text { rate if the inventory level is under the threshold. } \\
\text { - The ODPA produces on demand if the stock level is equivalent to the threshold. } \\
\text { - The ODPA will not produce if the stock level goes beyond the threshold. }\end{array}$ \\
\hline
\end{tabular}

Source: Adapted from Nielsen, P. \& Steger-Jensen, K., 2008, 'Demand planning \& control - Handling multiple perspectives through a holistic approach to hierarchical planning', in T. Koch (ed.), Lean business systems and beyond, p. 58, Springer, Boston, MA and Sethi, S., Yan, H., Zhang, H. \& Zhang, Q., 2002, 'Optimal and hierarchical controls in dynamic stochastic manufacturing systems: A survey', Manufacturing \& Service Operations Management 4(2), 6. https://doi.org/10.1287/msom.4.2.133.281

optimal demand planning approach may be considered more suitable for implementation in the manufacturing of fashion clothes. Hence, the adoption of these demand planning approaches depends on the product offering.

\section{Research design and methodology}

The study was both exploratory and descriptive in nature. Descriptive research was used to determine the demand planning practices among key stakeholders in the Gauteng clothing industry. The researchers made use of a survey. A survey involves obtaining data on situations, occurrences or events (Leedy \& Ormrod 2014:195). The clothing industry in South Africa is concentrated in the Western Cape, KwaZuluNatal, the Free State and Gauteng. The clothing industry in Gauteng comprises a population of 306 stakeholders (SACTWU 2012; Schreiber 2013). Among the total population in Gauteng, at the time of the study, 80 clothing industry stakeholders were based in Johannesburg, while Pretoria had 50 industry stakeholders. Johannesburg and Pretoria are the main cities in Gauteng. The population of the study were the clothing industry stakeholders (fabric suppliers, clothing manufacturers and fashion designers) in Gauteng. Gauteng was chosen because of convenience and accessibility.

The study followed a convenience non-probability sampling technique, as explained by Etikan, Musa and Alkassim (2015:1). According to Etikan et al. (2015:1), the convenience sampling technique can be used when selecting a population that poses many restrictions because of the particular nature of the population. The key criteria used when selecting the population was based on the expertise of the respondents regarding demand planning in the clothing industry. A structured questionnaire was administered using a five Likert-scale response format administered to $56 \mathrm{key}$ stakeholders in Pretoria and Johannesburg. The stakeholders consisted of 18 fabric suppliers, 26 clothing manufacturers and 12 fashion designers. The structured questionnaire was administered to clothing industry stakeholders such as managers and supervisors. To validate the research instrument, a pre-test was conducted. The questions were modified and 
refined accordingly based on feedbacks. For reliability, a consistent procedure was followed in the administration and analysis of the collected data.

\section{Ethical considerations}

Voluntary and anonymous questionnaires were emailed or hand-delivered to a sample of 56 respondents in the Gauteng clothing industry after obtaining permission from the Department of Department of Transport Economics Logistics and Tourism (TELT) and from the Department of Postgraduate Studies at the University of South Africa in 2011. The research proposal and the questionnaire were reviewed and approved by the ethics team. Cooper and Schindler (2011:252) declare that a questionnaire emailed through a personal computer provides more privacy than other methods of communication. A letter informing the respondents that the questionnaire was voluntary and that the information would be used for the purposes of completing a master's degree was sent to and signed by the respondents. A consent form was also sent to the respondents to confirm that they agree to complete the questionnaire.

With regard to ethical consideration, the respondents' consents were sought during the data collection process. The structured questions were analysed by means of SPSS.

\section{Results and discussion}

This section of the article presents the results and discussion of the structured questions. It begins with the demographic profiles of the respondents and followed by demand planning approaches employed in their organisations. The findings are presented using figures and tables.

\section{Demographic profile}

This section of the findings discusses the distribution of the clothing industry stakeholders as well as job positions of the clothing industry.

\section{The distribution of the clothing industry stakeholders}

Table 2 presents the distribution of the three key clothing industry stakeholders in percentages.

As shown in the Table 2, there are three stakeholders in the clothing industry. Of the stakeholders in the clothing industry, $46.4 \%$ were clothing manufacturers - thus nearly half of all the respondents. Fabric suppliers made up 32.1\% and $21.4 \%$ were fashion designers. This shows majority of the three key clothing industry stakeholders were clothing manufacturers.

TABLE 2: The clothing industry stakeholder distribution (in \%).

\begin{tabular}{lc}
\hline Clothing industry stakeholders & Percentage \\
\hline Clothing manufacturers & 46.4 \\
Fabric suppliers & 32.1 \\
Fashion designers & 21.4 \\
\hline
\end{tabular}

\section{The job position}

The job profile of the clothing industry is discussed in the subsection. Table 3 presents the job profile of the respondents in percentages.

As indicated in Table 3, the clothing industry stakeholders held various positions. Most of the clothing industry stakeholders were fabric specialists $(32.1 \%)$ followed by company owners (23.2\%) and operation managers (21.4\%). Minority of the clothing industry stakeholders were company directors $(1.8 \%)$, head of clothing supply chain $(1.8 \%)$, production supervisors $(1.8 \%)$ and specialist graphic designers $(1.8 \%)$. This indicates that majority of the respondents in this study were fabric specialist, company owners and operations managers.

\section{Demand planning approaches employed by industry stakeholders}

This subsection discusses findings on demand planning approaches employed by the key three stakeholders in the Gauteng clothing industry. To determine the approaches adopted by the respondents, the respondents were presented with 12 statements relating to the characteristics of demand planning approaches. The demand planning practices questions were measured using a five-point Likert-type response-format scale with 1 indicating 'strongly agree' and 5 'strongly disagree'. These statements and the respondents' responses are graphically presented in Figure 4 and summarised in Table 4.

More than $49 \%$ of respondents agreed and strongly agreed with statements relating to the characteristics of demand planning approaches. Figure 4 graphically presents the percentage of respondents who were in agreement with the various statements.

From Figure 4, it is clear that more than $50 \%$ of the three key clothing industry stakeholders are in agreement with the statements relating to demand planning approaches. As indicated in Figure 4, majority (over 80\%) of the respondents are in agreement with statements A1.3, A1.2 and A1.1 on the hierarchical approaches, namely that:

- It is necessary to conduct follow-up on material shortages with suppliers $(80.30 \%)$.

- It is important that manufacturers inform retail stores about stock shortages or any production problems (85.70\%).

TABLE 3: Job positions of respondents (in \%).

\begin{tabular}{ll}
\hline Position & Percentage \\
\hline Clothing designer specialist & 3.6 \\
Company director & 1.8 \\
Company owner & 23.2 \\
Fabric specialist & 32.1 \\
Fashion specialist & 3.6 \\
Head of clothing supply chain & 1.8 \\
Merchandise specialist & 5.4 \\
Operation manager & 21.4 \\
Production supervisor & 1.8 \\
Sales and operation manager & 3.6 \\
Specialist graphic designer (clothing) & 1.8 \\
\hline
\end{tabular}




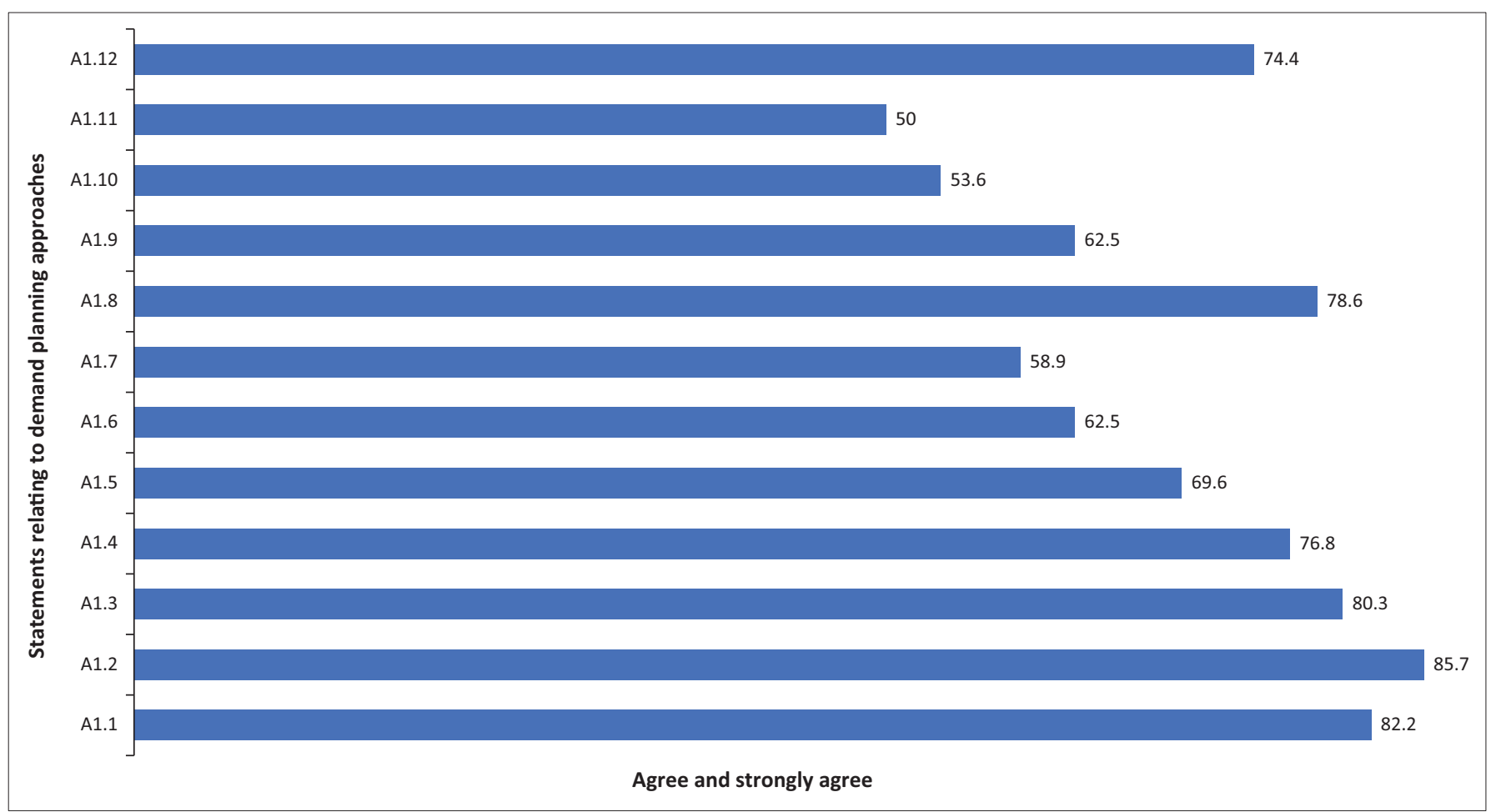

FIGURE 4: Perceptions on statements regarding demand planning approaches.

TABLE 4: Description of statements in Figure 4 relating to demand planning approaches.

\begin{tabular}{|c|c|c|c|}
\hline $\begin{array}{l}\text { Number of } \\
\text { statement }\end{array}$ & Statement & $\%$ agreement & Approaches \\
\hline A1.1 & $\begin{array}{l}\text { Continual reviewing of the product } \\
\text { process of the supply of clothes is } \\
\text { important. }\end{array}$ & 82.2 & $\begin{array}{l}\text { Hierarchical } \\
\text { and optimal }\end{array}$ \\
\hline A1.2 & $\begin{array}{l}\text { It is important that manufacturers } \\
\text { inform retail stores about stock } \\
\text { shortages or any production problems. }\end{array}$ & 85.7 & Optimal \\
\hline A1.3 & $\begin{array}{l}\text { It is necessary to conduct follow-up on } \\
\text { material shortages with suppliers. }\end{array}$ & 80.3 & $\begin{array}{l}\text { Hierarchical } \\
\text { and optimal }\end{array}$ \\
\hline A1.4 & $\begin{array}{l}\text { Manufacturing processes can only be } \\
\text { finalised when customers' orders and } \\
\text { specifications are confirmed. }\end{array}$ & 76.8 & Optimal \\
\hline A1.5 & $\begin{array}{l}\text { The manufacturing of clothes must be } \\
\text { completed before the sales season starts. }\end{array}$ & 69.6 & Optimal \\
\hline A1.6 & $\begin{array}{l}\text { It is important to have short-term } \\
\text { manufacturing plans for fashion clothes. }\end{array}$ & 62.5 & Optimal \\
\hline A1.7 & $\begin{array}{l}\text { Long-term manufacturing plans may exist } \\
\text { for basic clothes. }\end{array}$ & 58.9 & Hierarchical \\
\hline A1.8 & $\begin{array}{l}\text { Having manufacturers who think upfront } \\
\text { and react to market changes is crucial. }\end{array}$ & 78.6 & Optimal \\
\hline A1.9 & $\begin{array}{l}\text { Storing garment details according to size, } \\
\text { colour and design is crucial. }\end{array}$ & 62.5 & $\begin{array}{l}\text { Hierarchical } \\
\text { and optimal }\end{array}$ \\
\hline A1.10 & $\begin{array}{l}\text { There is a lack of capital equipment in } \\
\text { clothing manufacturing industries } \\
\text { in South Africa. }\end{array}$ & 53.6 & $\begin{array}{l}\text { Hierarchical } \\
\text { and optimal }\end{array}$ \\
\hline A1.11 & $\begin{array}{l}\text { Basic clothes are stable and result } \\
\text { in low variances when predicting future } \\
\text { demand. }\end{array}$ & 50 & Hierarchical \\
\hline A1.12 & $\begin{array}{l}\text { During a period of recession, it is crucial } \\
\text { to manufacture clothes in small batches. }\end{array}$ & 71.4 & Optimal \\
\hline
\end{tabular}

- Continual reviewing of the product process of the supply of clothes is important (82.20\%).

Over $70 \%$ of the respondents were also in agreement with statements A1.12, A1.8 and A1.4 on the hierarchical approaches, namely that:

- During a period of recession, it is crucial to manufacture clothes in small batches $(71.40 \%)$.
- Having manufacturers who think upfront and react to market changes is crucial $(78.6 \%)$.

- Manufacturing processes can only be finalised when customers' orders and specifications are confirmed $(76.8 \%)$.

Over $60 \%$ of the respondents agreed with statements in A1.9, A1.6 and A1.5, namely that:

- Storing garment details according to size, colour and design is crucial $(62.5 \%)$.

- It is important to have short-term manufacturing plans for fashion clothes $(62.5 \%)$.

- The manufacturing of clothes must be completed before the sales season starts $(69.6 \%)$.

The least $50 \%$ to $59 \%$ of the respondents agreed with statements A1.11, A1.10 and A1.7 that:

- Basic clothes are stable and result in low variances when predicting future demand (50\%).

- There is a lack of capital equipment in clothing manufacturing industries in South Africa (53.6\%).

- Long-term manufacturing plans may exist for basic clothes (58.9\%).

All these statements are presented in Table 4. The statements relate to the characteristics of demand planning approaches, which the three key clothing industry approaches adopt.

Table 4 indicates two types of demand planning approaches, which the three key clothing industry stakeholders may seem to adopt when making production decisions. 
From Table 4, it is clear that respondents agreed with the following statements A1.2, A1.4, A1.5, A1.6, A1.8 and A1.12, which relate to the optimal approach. The respondents agreed that:

- It is important that manufacturers inform retail stores about stock shortages or any production problems $(85.7 \%)$.

- Manufacturing processes can only be finalised when customers' orders and specifications are confirmed (76.8\%).

- The manufacturing of clothes must be completed before the sales season starts (69.6\%).

- It is important to have short-term manufacturing plans for fashion clothes $(62.5 \%)$.

- Having manufacturers who think upfront and react to market changes is crucial $(78.6 \%)$.

- During a period of recession, it is important to manufacture clothes in small batches $(71.4 \%)$.

The respondents were also in agreements with statements A1.1, A1.3, A1.9 and A1.10, which relate to both the hierarchical and the optimal approach, namely that:

- Continual reviewing of the product process of the supply of clothes is important (82.2\%).

- It is necessary to conduct follow-up on material shortages with suppliers (80.3\%).

- Storing garment details according to size, colour and design is crucial (62.5\%).

- There is a lack of capital equipment in clothing manufacturing industries in South Africa (53.6\%).

As indicated in Figure 4, both approaches are pursued by key stakeholders in the clothing industry. For example, when planning fashion clothes, fashion clothes are perceived to constitute small flexible production operations with many production uncertainties. These findings support the findings conducted by Sethi et al. (2002:6), which indicates that the optimal demand planning approach seems to function more efficiently in small flexible production operations with lots of production uncertainties. Also, the study conducted by Thomassey (2010:471), which states the characteristics hierarchical and optimal demand planning approaches, by elaborating that basic clothes are stable and constitute long manufacturing processes, whereas fashion clothes constitute constant changes and require short manufacturing processes. Authors such as Albey and Belge (2011:3320) alluded that optimal approach is also one of the demand management approaches, which assist in the production decision-making of organisations. This article presents two general approaches to demand planning practices that can be used in improving manufacturing performance as well as decision making in the clothing industry. The hierarchical demand planning approach is recommended on basic clothes, as basic clothes constitute large-scale stable operation processes with minimal uncertainties. The optimal demand planning approach is recommended for fashion clothes as it accommodates seasonal demand changes and the various fashion seasons. However, it is important to indicate that the adoption of these demand planning approaches depends on the product offering.

\section{Conclusion}

This article investigated demand planning approaches employed by the clothing industry stakeholders in Gauteng. A descriptive and exploratory survey was conducted among clothing industry stakeholders in Gauteng. Two demand planning approaches, namely, the hierarchical and optimal approaches are applicable in the clothing industry. Hierarchical demand planning approach seems to be more effective for basic clothes as they have a planning horizon of 12 months while optimal demand planning approach seems to be more effective for fashion clothes because they have a planning horizon of 6 months.

The article, therefore, suggests conditions under which clothing organisations can apply the approaches to demand planning in order to improve demand planning in their organisations. The article, therefore, contributes to the clothing industry in Gauteng, South Africa, by identifying the critical demand planning approaches that are worth considering when making manufacturing decisions to meet customer demand. It suggested that the clothing industry adopts the implementation of both the hierarchical and the optimal approaches in production demand planning. The key clothing industry stakeholders should apply the optimal demand planning approach to:

- improve demand forecast of clothing needs, especially regarding fashion clothes which change more often that basic clothes

- ensure that production takes place according to the maximum rate for the clothing stock level

- produce clothing garments on demand if the stock level is equivalent to the threshold.

The article deviates from other studies conducted in clothing industry of South Africa as it focuses mainly on demand planning approaches adopted by the clothing industry stakeholders in production planning. Studies conducted in South Africa focused on various components of demand planning such as planning for fashion clothes, scheduling, imports, forecasting, recession and wage settings. A limitation of the article is that only key clothing industry stakeholders in Gauteng (fabric suppliers, clothing manufacturers and fashion designers) were selected. It is not known whether the findings would have been different if all stakeholders in the country were part of the study. It will be important for other researchers and practitioners to draw lessons from this study to investigate demand planning practices in other parts of the country as well as the global community.

\section{Acknowledgements}

The authors would like to thank Retha Burger for assistance with technical and language editing. A special acknowledgement to the key clothing industry stakeholder of Gauteng for their participation in this research study. 
The authors would like to show their gratitude to Prof. Marcus Ambe who is a supervisor, a mentor and a coauthor in this research article.

\section{Competing interests}

The authors declare that they have no financial or personal relationships that may have inappropriately influenced them in writing this article.

\section{Authors' contributions}

N.J.M. and I.M.A. contributed to the writing of the article. This article is derived from the MCOM dissertation of N.J.M. I.M.A. was the supervisor of the MCOM dissertation.

\section{References}

African clothing industry in spotlight, 2014, Fin24.com, viewed from 15 March 2017 from http://www.fin24.com/Companies/Industrial/African-clothing-industry-inspotlight-20140415

Albey, E. \& Bilge, Ü., 2011, 'A hierarchical approach to FMS planning and control with simulation-based capacity anticipation', International Journal of Production Research 49(11), 3319-3342. https://doi.org/10.1080/00207543.2010.482570

Amusa, H., Amusa, K. \& Mabungu, R., 2009, 'Aggregate demand planning for electricity in South Africa: An analysis using bounds testing approach to cointegration' Energy Policy 37, 4167-4175. https://doi.org/10.1016/j.enpol.2009.05.016

Belmokhtar, S., Herrera, C. \& Thomas, A., 2010, 'A general approach for hierarchical production planning considering stability', in Proceedings of the 3rd International Conference on Information Systems, Logistics and Supply Chain, Creating Value through Green Supply Chain, ILS 2010 - Casablanca (Morocco), April 14-16, pp. 1-7.

Bowersox, D.J., Closs, D.J., Cooper, M.B. \& Bowersox, J.C., 2013, Supply chain logistics management, 4th edn., McGraw-Hill Irwin, New York.

Chan, F.T.S. \& Chan, H.K., 2010, 'An AHP model for selection of suppliers in the fast changing fashion market', The International Journal of Advanced Manufacturing Technology 51(9), 1192-1207. https://doi.org/10.1007/s00170-010-2683-6

Chaudhary, A., 2011, 'Changing structure of Indian textile industry after MFA (Mult Fiber Agreement) phase out: A global perspective', Far East Journal of Psychology and Business 2(2), 1-23.

Cooper, D.R. \& Schindler, P.S., 2011, Business research methods, 11th edn., McGraw Hill/ Irwin, New York.

Etikan, I., Musa, S.A., Alkassim, R.S., 2015, 'Comparison of convenience and purposive sampling', American Journal of Theoretical and Applied Statistics 5(1), 1-4. https://doi.org/10.11648/j.ajtas.20160501.11

Fibre2fashion.com, 2017, World of garments, textile and fashion, viewed 26 April 2017, from http://www.fibre2fashion.com/industry-article/2860/what-is-fashiondesign?page $=1$

Fibre Processing Manufacturing Seta (FP\&M Seta), 2014, 'Clothing, textile, footwear and leather sector: A profile of the clothing, textile, footwear and leather subsectors', in Fibre processing \& manufacturing sector education and training authority report, pp. 1-12, IQ business.

Hong, I.B., 2015, 'Understanding the consumer's online merchant selection process: The roles of product involvement, perceived risk, and trust expectation International Journal of Information Management 35(3), 322-336. https://doi. org/10.1016/j.ijinfomgt.2015.01.003

Isaacs, L., 2016, 'SA's clothing industry "must seize chances"', viewed 13 July 2017 from http://www.iol.co.za/business-report/economy/sas-clothing-industry-mustseize-chances-2031906

Isenheim, M., 2006, Quotas on textiles and clothing: A review, viewed 30 August 2012, from http://www.grin.com/en/e-book/51307/quotas-on-textiles-and-clothing-areview

Leedy, P.D. \& Ormrod, J.E., 2014, Practical research: Planning and design, 10th edn., Pearson Education, Harlow.

Media Club South Africa, 2015, South Africa's economy: Key sectors, viewed 08 April 2015, from http://www.mediaclubsouthafrica.com/africa/37-economy/economybg/111-sa-economy-key-sectors

Nattrass, N. \& Seekings, J., 2012, Differentiation within the South African clothing industry: Implications for wage setting and employment, CSSR. Working Paper no. 307, Centre for Social Science Research, University of Cape Town, Cape Town, pp. 1-29.
Nenni, M.E., Guistiniano, L. \& Pirolo, L., 2013, 'Demand forecasting in the fashion industry: A review', International Journal of Engineering Business Management: Special Issue on Innovations in Fashion Industry 5(37), 1-6. https://doi.org/ Special Issue on
$10.5772 / 56840$

Nielsen, P. \& Steger-Jensen, K., 2006, 'The need for a holistic demand planning framework', in International Conference on Information Systems, Logistics and Supply Chain, Aalborg University, Aalborg Oest, Denmark, 1-5th May.

Nielsen, P. \& Steger-Jensen, K., 2008, 'Demand planning \& control - Handling multiple perspectives through a holistic approach to hierarchical planning', in T. Koch (ed.), Lean business systems and beyond, pp. 57-65, Springer, Boston, MA.

NY Fashion Center, 2015, The history of fabric and textiles, viewed 01 October 2015 from https://www.nyfashioncenterfabrics.com/pages/history-of-fabric-and-textiles

Oberhofer, M.A., 2012, 'Fashioning African cities: The case of Johannesburg, Lagos and Douala', Streetnotes 20(1), 65-89.

Omar, M.K. \& Teo, S.C., 2007, 'Hierarchical production planning and scheduling in a multi-product, batch process environment', International Journal of Production Research 45(5), 1029-1047. https://doi.org/10.1080/00207540600724989

Oyatoye, E.O. \& Fabson, T.V.O., 2011, 'Information distortion in supply chain: A simulation approach to quantifying the bullwhip effect', Journal of Emerging Trends in Economics and Management Sciences 2(2), 131-141.

Priest, A. 2005, 'Uniformity and differentiation in fashion', International Journal of Clothing Science and Technology 17(3/4), 253-263.

Pycraft, M., Sigh, H., Philela, K., Slack, N., Chambers, S. \& Johnston, R., 2013, Operations management: Global and southern African perspectives, 2 nd edn., Pearson Education South Africa, Cape Town.

Ramdass, K., 2007, 'Engineering management framework for the SA clothing industry with the focus on KwaZulu-Natal', Unpublished DPhil thesis, University of Johannesburg, Johannesburg.

Rexhausen, D., Pibernik, R. \& Kaiser, G., 2012, 'Customer-facing supply chain practices: The impact of demand and distribution management on supply chain success', Journal of Operations Management 30(4), 269-281. https://doi.org/10.1016/j. journal of Operation

Rogerson, C.M., 2000, 'Successful SMEs in South Africa: The case of clothing producers in the Witwatersrand', Development South Africa 17(5), 687-716. https://doi. org $/ 10.1080 / 713661433$

Salm, A., 2002, South African garment industry subsector study. South Africa, The ComMark Trust, Johannesburg.

Schreiber, G., 2013, The South African fashion handbook, Schreiber Media, Cape Town.

Sethi, S., Yan, H., Zhang, H. \& Zhang, Q., 2002, 'Optimal and hierarchical controls in dynamic stochastic manufacturing systems: A survey', Manufacturing \& Service Operations Management 4(2), 133-170. https://doi.org/10.1287/msom.4.2.133.281

Sen, A., 2008, 'The US fashion industry: A supply chain review', International Journal of Production Economics 114(2), 571-593.

Shen, B., Choi, T.M., Wang, Y. \& Lo, C.K.Y., 2013, 'The coordination of fashion supply chains with a risk - Averse supplier under the markdown money policy', IEEE Transactions on Systems, Man, and Cybernetics: Systems 43(2), 266-276. https:// Transactions on Systems, Man, and Cybern
doi.org/10.1109/TSMCA.2012.2204739

Skov, L., 2011, 'Dreams of small nations in a polycentric fashion world', Fashion Theory 15(2), 137-156. https://doi.org/10.2752/175174111X12954359478609

South African fashion week, 2015, viewed 18 March 2017, from http://www. safashionweek.co.za/category/designers/black-coffee/

SouthAfrica.info, 2015, South Africa's textile industry, viewed 01 October 2015, from http://www.southafrica.info/business/economy/sectors/textiles-overview.htm

Southern African Clothing and Textile Workers Union (SACTWU), 2012, Manufacturing address list for sale, NBC (Northern) FMR064G, SACTWU, Johannesburg.

Staritz, C. \& Morris, M., 2013, 'Local embeddedness, upgrading and skill development: Global value chains and foreign direct investment in Lesotho's apparel industry', in Economic and Social Upgrading in Global Production Network, Working Paper no 20, South Africa, University of Cape Town, 1-25th February.

Steytler, N. \& Powell, D., 2010, 'The impact of the global financial crisis on decentralised government in South Africa', paper presented at the Annua Conference of the International Association of Centres for Federal Studies, Philadelphia, PA, 16-18th September.

Thomassey, S., 2010, 'Sales forecasts in clothing industry: The key success factor of the supply chain management', International Journal of Production Economics 128(2), 470-483. https://doi.org/10.1016/j.ijpe.2010.07.018

Vlok, E., 2006, 'The future of the textile and clothing industry in sub-Saharan Africa: The textile and clothing industry in South Africa', Bonn: Friedrich-Ebert-Stiftung 229, 227-236.

Wark, M., 2006, 'Fashion the future: Fashion, clothing, and manufacturing of postFordist culture', Cultural Studies 5(1), 61-76.

Williams, W., 2015, 'Investigation into the critical success factors for the implementation of a quick response supply chain strategy in the South African fashion apparel sector', Master's in Business Administration (MBA), South Africa, University of Stellenbosch, pp. 1-97. 